\title{
THE EFFECT OF COMMUNITY PARTICIPATION AND ROLE OF REGIONAL GOVERNMENT AND PRIVATE SECTOR TOWARDS THE SUCCESS OF TOURISM VILLAGE: A CASE STUDY IN AMBENGAN VILLAGE AS A TOURISM VILLAGE IN SUKASADA DISTRICT OF BULELENG REGENCY, INDONESIA
}

\author{
Suwaryanthi Luh Meylin*, Setiawina Nyoman Djinar, Yasa I G. W. Murjana, \\ Wardana I Gede \\ Faculty of Economics and Business, University of Udayana, Bali, Indonesia \\ *E-mail: luhmelin@rocketmail.com
}

\begin{abstract}
Tourism village as one of the destinations for diversifying tourism destinations increases the participation of the society in tourism activities in each region in order to realize a prosperous society. This research was conducted in Ambengan Village, Sukasada District, Buleleng Regency to analyze community participation, the role of regional government and the private sector to oppose the development of the tourism village. The results of this study indicate community participation, the role of regional government and the role of the private sector which have a positive and significant effect on the success of the tourism village. The role of regional government has a positive and significant effect on public participation and the role of the private sector. The role of regional governments is directly and positively related to the success of the tourism village through community participation. The role of regional government is directly and positively related to the success of a tourism village through the role of the private sector.
\end{abstract}

\section{KEY WORDS}

Community participation, regional government, private role, tourism, village.

One of the policies of the Bali Provincial Government in the tourism sector is the tourism village development program. Tourism village as an effort to diversify tourist destinations, and increase the role of the society in tourism development in their respective regions in order to create a prosperous society. The success of developing tourism village requires the support and the acceptance from local societies (Wearing, 2000 in Dewi, 2014). So, the neglect of community participation will lead to the failure of the development of the tourism village itself (Dewi, 2014). Community participation in the development of tourism village is in line with the development of community-based tourism. Through the development model of community-based tourism, it is believed that it can strengthen the ability of rural societies to manage tourism resources where societies are fully involved. According to Arnstein in Dewi (2013) participation is a strength that is owned by the society to solve problems in the present. Then, a better life can be achieved in the future.

In addition to the role of government and community participation in the development of tourism, the role of the private sector is also needed. The role of the private sector includes in the effort of integrated promotion between tourism managers, manufacturing and marketing tour packages, holding various training and running businesses that support tourism activities.

The advantage to being achieved through the establishment of the tourism village include improving village infrastructure, improving the quality of settlements, increasing income, improving the quality of human resources (HR), transferring knowledge to the society, decreasing urbanization which in turn encourages improvement in societies' welfare (Disparda Bali, 2013).

Buleleng as one of the regencies in Bali Province has the highest poverty rate in Bali. It participating in developing its village and has the potential to be developed as the tourism village. This is an effort to diversify tourist destinations that are expected to increase the 
visitors, while at the same time having an impact on the welfare of the society which is still concentrated in the south of Bali.

Furthermore, Ambengan village is one of the tourism villages in Buleleng regency which has a superior tourism potential such as waterfalls, the panorama of rice fields, and handicrafts of banana midribs in the form of photo albums and woven bamboo crafts. Ambengan Village as one of the tourism villages in Buleleng regency was determined through the Buleleng Regent Decree no. 430/927 / HK / 2015 on December 21 $1^{\text {th }}, 2015$.

The problems that arise in the Ambengan village include accessibility and amenities. As in Bukit Balu waterfall, the sub-district agency of Bukit Balu is still difficult to be accessed by a car. It is due to the unfavorable terrain. To reach the Bukit Balu waterfall in Bukit Balu Hamlet, the visitors have to travel about 800 meters by walking from the parking area. Even though toilet facilities have been available as a dressing room, but the location is far away from the waterfall. It cannot be utilized according to their designation. Besides, the problems also arise related to the quality of human resources. The low quality of human resources is caused by members of tourism conscious groups and managers of tourist attraction which is dominant as the farmers. Promotional efforts related to the existence of tourism village are still lacking. However, cooperation with relevant stakeholders is needed to make the Ambengan village can be better and possibly known not only by domestic tourists but also by foreign tourists (rri.co.id, 2017).

Although it has been designated as a tourism village since December 21, 2015, and it has been given guidance on tourism awareness groups, also several times physical assistance from both the central government and the provincial government, but the success of Ambengan as a tourism village has not been maximal as what it expected before.

\section{LITERATURE REVIEW}

Tourism village is a region with a certain area and has the unique potential of a unique tourist attraction with its community that is able to create a combination of various tourist attractions and supporting facilities to attract the visitors (Director General of Tourism Destination Development, 2014)

While Nuryanti (1993) defines tourism villages as a form of integration between attractions, accommodations, and other supporting facilities presented in the structure of societies' life with the prevailing traditions.

Tourism village development is a process that urges the ways to develop or promote tourism villages (Pearce, 1995). Develop tourism villages to complement needs and improve tourist facilities to meet tourist needs. Tourism villages should fulfill four main components, namely attraction, accessibility, amenities, ancillary (supporting factors) which is included the availability of an organization and human resources supporting tourism activities (Cooper et al. 2005).

The definition of regional government as stipulated in Law number 23 of 2014 stated that regional government is the regional head and other autonomous regions as regional executive bodies. Furthermore, the regional government is a government agency that knows the potential of the region and the needs of the local people.

According to Adisasmita (2006), community participation in the social empowerment which plays a role in the activities of planning and implementing development programs or projects, it also the actualization and willingness of the community to sacrifice and contribute to the implementation of development programs.

As stated by Huraerah (2008), the form of community participations is ideas participation, labor participation, properties, skills of participation, and social participation.

Increasing the role of the private sector is one of the government's efforts in fulfilling excellent infrastructure and services to society (Manupassa, Erine Aneta, 2011). The development of tourism potential can be done by building cooperation between the regional government and the private sector based on the consideration of efficiency and effectiveness. 
In the management model of tourism resources based on the community participation, the private sector as the investors, other tourism actors, including universities and nongovernmental organizations (Dewi, 2013).

According to Sumodiningrat (1999), participation is an element of development in the process of human adaptation to ongoing changes. The prerequisites for the sustainable development process including all of the society at each stage of development.

In the Law of the Republic of Indonesia, Number 10 of 2009 concerning tourism stated that one of the principles in the implementation of tourism is must be able to empower the local society. So that the community is an important component which must be considered by involving them in the tourism activities and respecting their priority rights.

Tasci in Suasapha (2015) argues that the success of community-based tourism is when it is able to provide the economic benefits in the form of increasing the society income through the benefits in business and employment opportunities, alleviating poverty, restoring economic conditions and improving the infrastructure.

Community-based tourism (CBT) is the structure of the community-based tourism industry and local communities who are considered as owners (Cavaye, 2000, in the team for tourism development economic research, 2014).

Community-based tourism development requires the collaboration between parties such as government, society, tourism businesses, non-governmental organizations (NGOs), universities and research institutions (CIFOR, 2004).

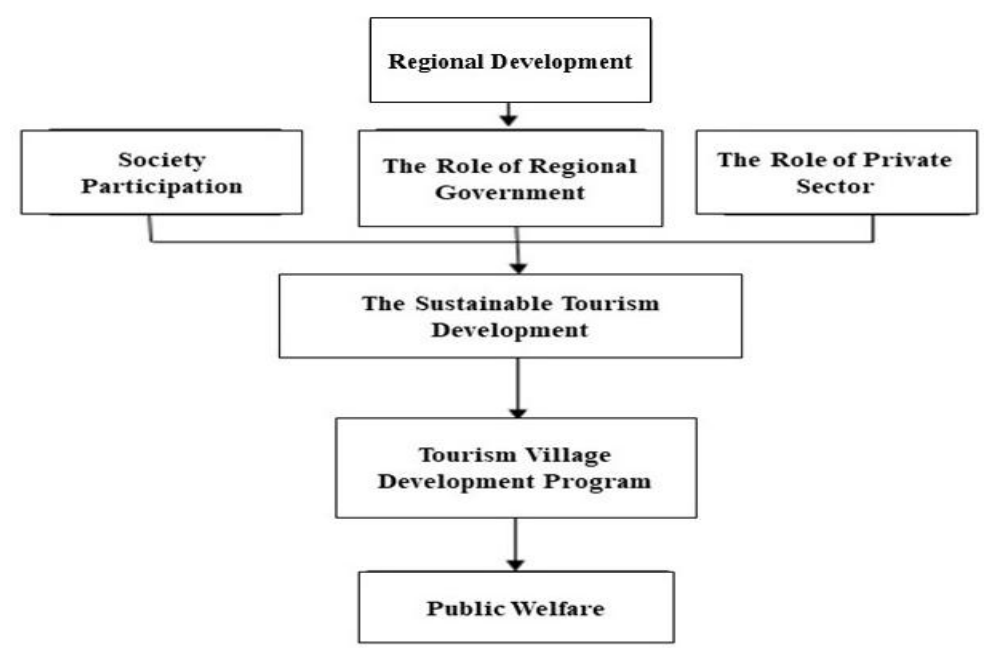

Figure 1 - The Framework for tourism village development program

\section{METHODS OF RESEARCH}

Based on the literature the following research hypothesis can be formulated as below:

- Community participation, the role of regional government and the role of the private sector has a positive and significant impact on the success of Ambengan tourism village in Sukasada district, Buleleng Regency.

- The role of the regional government has a positive and significant impact on community participation in Ambengan as the tourism villages.

- The role of regional government has a positive and significant impact on the role of the private sector in the village of Ambengan.

- There is an indirect impact on the role of regional governments in the success of Ambengan tourism villages through community participation.

- There is an indirect impact on the role of regional government in the success of Ambengan tourism villages through the role of the private sector.

The method used in this analysis was a quantitative method. The technique used test of data instruments that include validity and reliability tests. This study used Partial Least 
Square (PLS) which consists of a measurement model or outer model and structural model or inner model.

In this study, the subjects of the research were the Ambengan villagers. It focused on the characteristics of the research subjects, namely the local society who played a role in the tourism village. The Ambengan villagers who played a role in the tourism village included the Banten Sari tourism group which consists of 24 people. In addition, the community leaders of Ambengan Village are also considered to be able to represent the characteristics of the research subjects. Emphasis on the community leaders in Ambengan village as the person who capable of representing the opinions of the people stated that they represent and can provide positive input for the progress and villagers welfare. Community leaders in Ambengan Village consist of formal and informal figures. A formal community figure is someone who is named because of his position or position in the government. An informal community figure is an informal leader in his community who is appointed by the will of his community. To strengthen the results of the research survey, the opinion of the Village Devices and Members of the Village Consultative Body (BPD) of Ambengan Village is also very necessary.

The dependent variable in this study is community participation that plays a role in tourism villages $(X 1)$, the role of the private sector $(X 3)$ and the success of tourism village (Y1) from the role of regional government (X2).

The independent variable is community participation that plays a role in tourism village $(\mathrm{X} 1)$, the role of regional government (X2), and the role of the private sector (X3) on the success of Tourism Village (Y1).

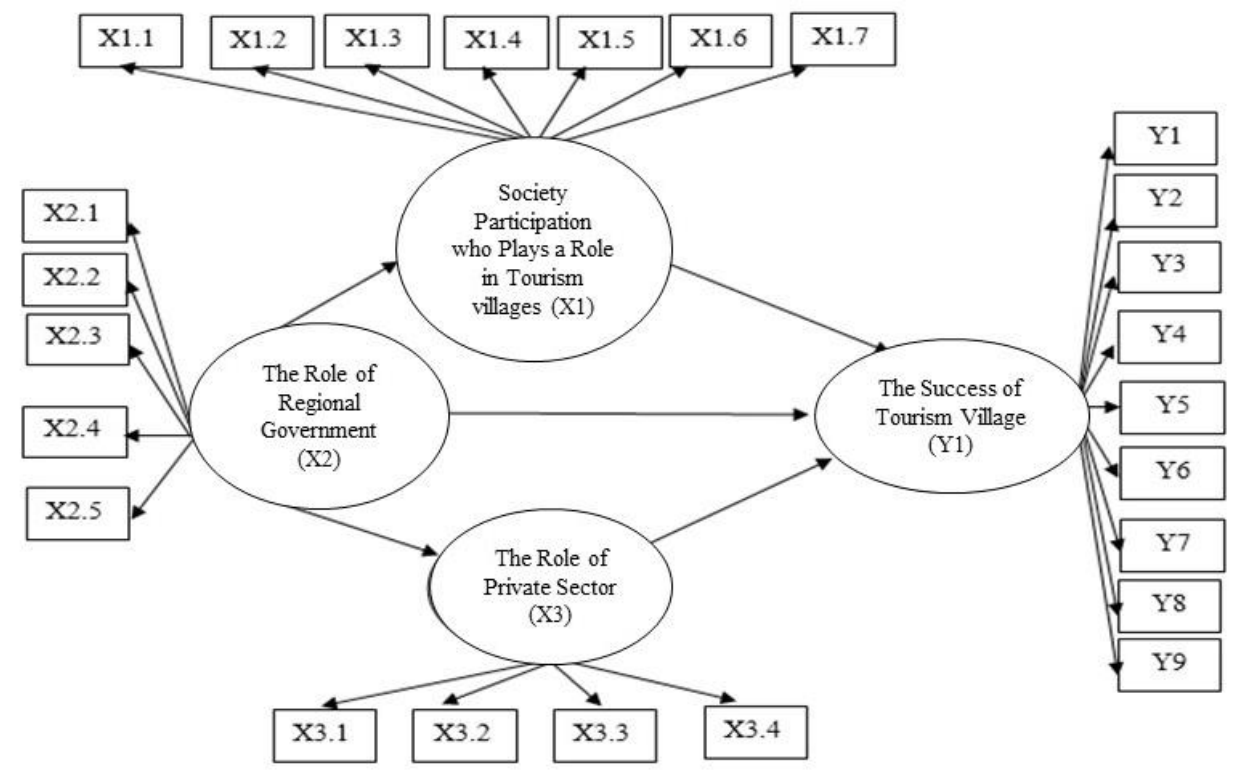

Figure 2 - The Framework of research and inter-variable relationships

\section{RESULTS AND DISCUSSION}

The total determination coefficient of the structural equation from this research model shows that 77.6 percent of the success variables of tourism village can be explained by the research model, while the data which excluded is explained by other variables outside the research model.

The results of hypothesis testing indicate that community participation in tourism villages has a positive and significant effect on the success of tourism village in Ambengan tourism village with a regression coefficient of 0.472 . The role of regional government has a positive and significant effect on the success of Ambengan tourism village in Buleleng Regency by looking at the regression coefficient of 0.219 . The private sector also has a 
positive and significant effect on the success of ambengan tourism village in Buleleng Regency by looking at the regression coefficient of 0.337 .

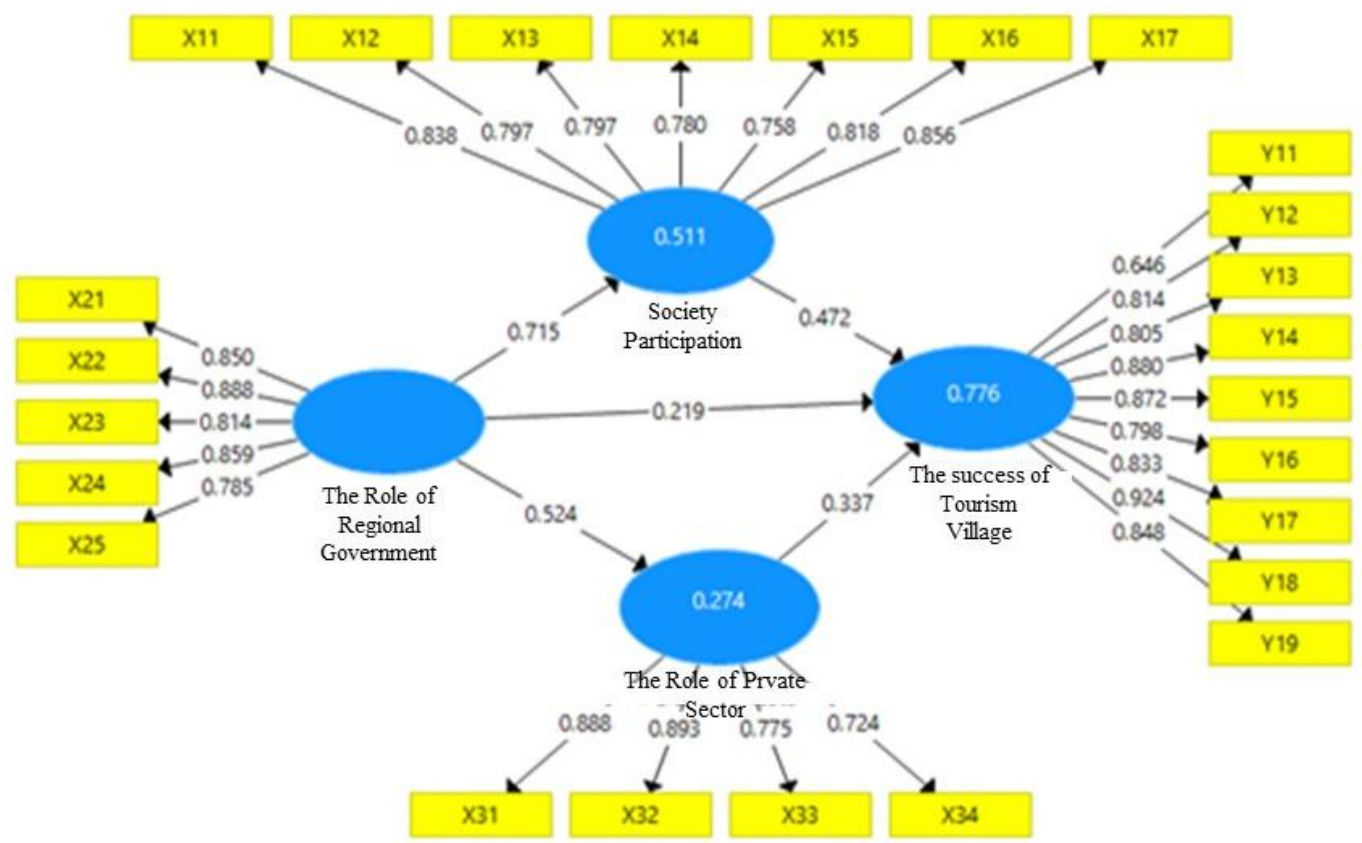

Figure 3 - Full model of estimates result society participation impact, the role of regional and private governments on the success of tourism villages

The role of regional government has a positive and significant effect on community participation that plays a role in the tourism village with a regression coefficient of 0.715 . The role of regional government has a positive and significant effect on the role of the private sector in the tourism village with a regression coefficient of 0.524 .

Table 1 - Direct impact inter-variable

\begin{tabular}{|c|c|c|c|c|c|c|}
\hline \multicolumn{2}{|c|}{ Relation of inter-variable } & Loading & Sterr & Tstatistik & $p$ value & Ket \\
\hline (X1) & (Y1) & 0.472 & 0.105 & 4.498 & 0.000 & Sig \\
\hline$(\mathrm{X} 2)$ & (X1) & 0.715 & 0.087 & 8.188 & 0.000 & $\mathrm{Sig}$ \\
\hline$(\mathrm{X} 2)$ & $\longrightarrow$ & 0.524 & 0.116 & 4.507 & 0.000 & Sig \\
\hline$(\mathrm{X} 2)$ & $\longrightarrow$ & 0.219 & 0.107 & 2.048 & 0.041 & Sig \\
\hline (X3) & $\longrightarrow$ & 0.337 & 0.102 & 3.290 & 0.001 & Sig \\
\hline
\end{tabular}

The variable role of regional government (X2) which influences the success of tourism village (Y1) in Ambengan village, Buleleng Regency through the mediating role of community participation in the tourism village has a loading value of 0.337 while the role of regional government variables on tourism village success $(\mathrm{Y} 1)$ through mediation the private role has a factor loading of 0.177 .

Table 2 - Indirect impact inter-variable

\begin{tabular}{cccrc}
\hline Relation of inter-variable & $\begin{array}{l}\text { Original } \\
\text { Sample }\end{array}$ & Sterr & $\begin{array}{c}\mathrm{T} \\
\text { Statistik }\end{array}$ & $\begin{array}{c}\mathrm{P} \\
\text { Value }\end{array}$ \\
$(\mathrm{X} 2) \rightarrow(\mathrm{X} 1) \rightarrow(\mathrm{Y} 1)$ & 0.337 & 0.086 & 3.908 & 0.000 \\
$(\mathrm{X} 2) \rightarrow(\mathrm{X} 3) \rightarrow(\mathrm{Y} 1)$ & 0.177 & 0.069 & 2.549 & 0.011 \\
\hline
\end{tabular}




\section{DISCUSSION OF RESULTS}

The results of the analysis in this study show that the influence of community participation on the success of Ambengan tourism village is positively and significantly influential. This is in line with the results of research by Rafael Modestus Ziku (2013) stated that community participation in the development of eco-tourism in Komodo Island was analyzed by qualitative descriptive analysis techniques that were positively valued. Positive community participation is due to the great motivation to obtain economic benefits from ecotourism both related to increasing community income from eco-tourism businesses as well as the opening of new employment opportunities for the society. It also supported by stakeholders who play a role in motivating community participation.

In Mertha's research (2015) it was proven that the local community participation had a positive and significant impact on the quality of the destination of Batur Geopark Kintamani. It confirms the opinion of Tosun (2003) that the importance of community participation from the planning and development stages of tourism. So that the benefit can directly be given from tourism activities which in turn encourages the society to play an active role in the preservation of local resources. "Community participation increases tourist satisfaction", that has good support and acceptance from the society will create a positive impression for the visitors.

Community participation that plays a role in the Ambengan tourism village includes participation in ideas and labor participation. Community participation shows that community involvement in the development of tourism villages has been from the planning stage, through donations of thoughts on each socialization related to the development of tourism village plans. Likewise, with participation in the form of energy, through physical support in the construction of parking facilities in Jembong Waterfall and mutual cooperation on a regular basis in an effort to maintain the cleanliness of the village. In addition, the local people work together to make roads independently to Bukit Balu waterfall. The Ambengan tourism village program has been well socialized by the regional government to the local society. The high level of community participation in Ambengan tourism villages is due to the benefits obtained in the form of increased employment opportunities and increased income for the local society. The Head of Ambengan Village says that:

"A huge community participation in Ambengan tourism village in realizing village cleanliness is also one of the attractions for the tourists. A clean, beautiful and neatly arranged environment will create good impressions or memories for the tourists who are the embodiment of the "Sapta Pesona" (seven charms)".

The hypothesis shows that the role of the regional government has a positive and significant impact on the success of the Ambengan tourism village in Buleleng Regency. It proves that the seriousness of the regional government in realizing Article 4 of the Bali Cultural Tourism Regional Regulation No.2 of 2012 to improve the welfare of the Balinese people equally and sustainably through the development of tourism villages.

This research is in line with Bahagia's research (2008) that the regional government plays a role in the rehabilitation of mangrove forests in Baitussalam District. The planning for the rehabilitation of mangrove forests is carried out by the government supported by the assistance of donor agencies or NGOs. The government provides formal and non-formal counseling to the community to increase public understanding of mangrove conservation.

The regional government as a facilitator has provided assistance in the form of gradual physical infrastructure improvements in the Ambengan village which preceded by paving the road to the waterfall in December 2017. In terms of human resource development for the local society, the guidance has been carried out for tourism conscious groups from both the provincial and the district government.

The results showed that the role of the private sector had a positive and significant impact on the success of Ambengan tourism village in Buleleng Regency, the role of the private sector was very helpful in the success of Ambengan tourism village.

According to Dewi (2013), the community-based tourism resource management model is a synergy of stakeholders, such as the government, the society and the private sector that 
is directed and responsible according to their respective roles. Private in this model are not only elements of investors and tourism business players but also the elements of NGOs and universities. Likewise, increasing the role of the private sector is one of the government's efforts to fulfill the infrastructure and excellent service to the community based on efficiency and effectiveness (Manupassa, Erine Aneta, 2011).

Furthermore, some universities have conducted training such as English language training for local people involved in tourism activities. For example, Ganesha Education University (Universitas Pendidikan Ganesha), as well as the Nusa Dua Tourism College (Sekolah Tinggi Pariwisata Nusa Dua). They also made a brochure to promote tourism in Ambengan Village as one of its service activities to society.

The results of this study indicate that the role of regional government has a positive and significant effect on community participation that participates in tourism village. It confirms the opinion of Pitana and Gayatri (2005) which said the regional government serves to provide motivation in the development of tourism for the investors and tourism entrepreneurs. Tosun (2003) emphasized that community participation helps professional tourism design better tourism plans which through involving community participation will help planners or governments to design better forms of tourism.

The role of regional government in Ambengan village through their efforts to increase community participation in tourism activities by building cooperation with universities. The cooperation is in the form of community service activities in Ambengan tourism village. It has been done by the College of Tourism (Sekolah Tinggi Pariwisata) and Education University of Ganesha (Universitas Pendidikan Ganesha) which has given the training of some foreign language to the local society.

The results of this study showed that the role of the regional government had a positive and significant impact on the private role in Ambengan tourism village. These results also indicate that the role of the regional government represented by respondents determines the strength of the private role in the Ambengan tourism village of Buleleng Regency. In Manupassa's research (2011) emphasized that increasing the role of the private sector is one of the government's efforts to fulfill infrastructure and excellent service to the society based on consideration of efficiency and effectiveness. In the development of tourism villages, the community-based tourism resource management model meant by the private sector includes investors, tourism business actors, universities and NGOs (Dewi, 2013).

Moreover, the results of this study also indicate that the role of the regional government has a positive and significant indirect impact in the success of Ambengan village in Buleleng Regency through community participation which plays a role in tourism villages.

After all the explanation above, there are some strength and the weakness of community participation that plays a role in tourism villages which be able to influence the success of Ambengan tourism village. In line with the statement of the Director General of Tourism Destination Development (2014), the existence of tourism villages which is diversification of tourism products aims to involve the community in tourism activities. Economic activities in rural areas based on tourism activities will minimize the potential for the urbanization of people from rural to urban areas.

The role of the regional government was affirmed by Munir (2010) as the coordinator who embraced the community to become the actors in the development. Morgan's statement in Mertha (2015) emphasizes the role of government in the formulation of policies can give the benefit for the minority community through empowering local communities.

The Bali Mandara volume 2 program in the field of tourism raised up Ambengan village as the tourism village. The development of the Ambengan tourism village which aims to increase community participation in tourism development can work together and make the relevant cooperation with the stakeholders in improving the quality of tourism development in the region. The success of Ambengan tourist villages requires the participation of local society who must be consistently motivated by the regional government.

The significant influence of the role of the regional government through community participation in the success of Ambengan tourism village is greater than the significance of 
the direct influence of the role of regional governments on the success of Ambengan tourism village. Mr. Gede Suberta, the Head of Ambengan village stated that:

"The duty of the regional government in realizing the success of Ambengan tourism village is quite complex. There are many things still need to be prepared, such as the infrastructure, improving the quality of human resources and providing amenities. Through regular community participation in carrying out mutual cooperation activities every week and months of annual community service activities, the Ambengan tourism village can be well organized and maintained. The provision of parking around the tourist attractions of Jembong Waterfall and Pebantenan Waterfall by the local society is one form of efforts to provide amenities in Ambengan tourism village. Through open the road access to Bukit Balu Waterfall is also carried out independently and works together with the society. They are very enthusiastic in receiving training from universities that are conducting community service activities. Certainly, good community participation will be able to increase the success of Ambengan tourism village".

The results of this study show that the role of the regional government has a positive and significant indirect impact in the success of the Ambengan tourism village in Buleleng Regency through the private role.

From the other perspective, Mr. Made Suneka as the coordinator of tourism group in Sub-district Jembong (Banjar Dinas Jembong) stated that:

"The private sector which is from universities helps the development of tourism in Ambengan tourism village. The intended universities include the University of Education Ganesha and the Nusa Dua Bali Tourism College. Through community service activities, students provide foreign language training, especially English. They make a trekking tour package brochure for Jembong Waterfall and Aling-Aling Waterfall. The activities that have been carried out by the students are quite helpful in the effort to increase the human resources and the marketing of Ambengan tourism village".

\section{CONCLUSION AND RECOMMENDATIONS}

Based on the foregoing discussion, the conclusion of this study is explained as follows:

- Community participation, the role of regional government, and the role of the private sector have a significant impact on the success of Ambengan tourism village. If community participation, regional government and the role of the private sector increase, it will increase the success of Ambengan tourism village in Sukasada District, Buleleng Regency too;

- The role of the regional government has a significant impact on community participation in Ambengan tourism village. If the role of the regional government increases, community participation in Ambengan tourism village also increases;

- The role of regional government has a significant impact on the role of the private sector in Ambengan tourism village. If the role of regional government increases, the role of the private sector in Ambengan tourism village also increases;

- The role of the regional government has an indirect impact on the success of Ambengan tourism village through the community participation;

- The role of the regional government has an indirect impact on the success of Ambengan tourism village through the role of the private sector.

Based on the results of this study, there are suggestions that explained as below.

To improve the accessibility which focuses on the widening rebates of Jembong Waterfall, it needs an effort to repairing and widening the narrow road to the waterfall in Subdistrict of Pebantenan (Banjar Dinas Pebantenan). Then, the road to Bukit Balu Waterfall which is still difficult to reach by vehicles is also need to be repaired. Moreover, the realization to expand the parking area must be done immediately in order to provide the service of the tourist attractions.

The effort of regional governments to realize the success of Ambengan tourism village from an element of amendment to make improvements and additions to supporting tourism activities such as toilets, fitting rooms, gazebos and counter tickets. 
The effort of the regional government to realize the success of Ambengan Tourism Village from the element of tourism resources should be able to provide various tourism training that is carried out continuously.

The regional government needs to make the cooperation with travel agents in order to promoting and marketing Ambengan tour packages. It can be promoted through the digital media by creating a website of Ambengan tourism village. It is an effort that can be realized besides conducting meetings, social gathering, and festivals in Ambengan Tourism Village.

In realizing the success of Ambengan tourism village, especially in the tourist attraction sector, the community participation should be enriching the local cultural tourism as the routinely art performance for tourists. The local cultural tourism mentioned namely Rejang Dee dance, Truna dance and Mabuang dance. Those are sacred dances which are danced during the big ceremony (piodalan agung) in Desa temple and Bukit temple. However, tourists who want to take a closer look can come to the temple with traditional customs.

In realizing the success of tourism villages from attractions and amenities sector, the community participation should be make and sell souvenirs from Ambengan village. It can be a promotional tool in the tourists' hometown. The souvernir mentioned is the village community crafts which usually make photo albums from banana midribs, vegetable baskets and hollow baskets.

In realizing the success of tourism villages, the role of private sector should be increase the attractive tourist package and integrate with other tourist attractions around Ambengan tourism village. The form of cooperation can be the package of Ambengan tourist village combined with the activity of enjoy tropical fruits in Bangkiang Sidem Village, or can be combined with visiting Sambangan tourism village. The other package can be the Ambengan tourism village combined with the city tour around Singaraja city, etc.

In order to realize the linkage of Ambengan tourism village with the other villages, the tour package can be collaborated with the tour package of Ambengan dan Sambangan tourism village. This is inseparable from the efforts of the community and the private sector to work hand in hand to realize the diversification of tourist attraction in Buleleng Regency.

The suggested role of the private sector is to carry out activities that are beneficial and can involve the community, like garbage processing activities. If every community has been able to carry out waste management independently it will have a good quality of life as part of the realization of the seven charms (Sapta Pesona) which consists of secure, orderly, clean, cool, beautiful, friendly, and memorable.

\section{REFERENCES}

1. Adisasmita, Raharjo. 2006.Membangun Desa Partisipatif.Yogyakarta: Graha Ilmu

2. Antara, I Ketut. 2011. "Strategi Pengembangan Pariwisata di Desa Pelaga Kecamatan Petang Kabupaten Badung" (thesis). Denpasar: Universitas Udayana.

3. Antariksa, Basuki. 2012: Peluang dan Tantangan Pengembangan Kepariwisataan di Indonesia: Pusat Penelitian dan Pengembangan Kepariwisataan Kementerian Kebudayaan dan Pariwisata. [online] available from http://www.kemenpar.go.id [Accessed 1 Mei 2017]

4. Anwar, Saiful dan Rida Perwita Sari. 2009. Pengaruh Partisipasi Masyarakat dan Transparansi Kebijakan Publik terhadap Hubungan antara Pengetahuan Dewan Tentang Anggaran dengan Pengawasan Keuangan Daerah. Jurnal Strategi Akutansi [online] Vol.1 $\begin{array}{lllll}\text { Nomor } & 2 & \text { Juli } & 2009 . & \text { Available }\end{array}$ http://ejournal.upnjatim.ac.id/index.php/strategi_akutansi/article/vi ewfile/157/131[accessed1 Mei 2017]

5. Ardita, I Komang Agus. 2011. "Analisis Faktor-Faktor yang Menentukan Kualitas Kinerja Pelayanan Publik pada Kantor Pelayanan Perijinan Terpadu Kabupaten Jembrana". (thesis). Denpasar: Universitas Udayana.

6. Arnstein, Sherry R. 1969. A Ladder of Citizen Participation Journal of The American Institute of Planners. [Online] Available from http://lithgow-schmidt.dk/sherryarnstein/ladder-of-citizen- participation en doc [accessed on 6 Juli 2017]. 
7. Bahagia.2009. "Peran Pemerintah Daerah dan Partisipasi Masyarakat Dalam Rehabilitasi Hutan Mangrove Pasca Tsunami di Kecamatan Baitussalam Tahun 2008" (thesis). Medan: Universitas Sumatera Utara.

8. Basuki, Ananto dan Sofyan. 2006. Penguatan Pemerintahan Desa berbasis Good Governance. Malang: SPOD.

9. Centre For International Forestry Research (CIFOR).2004: Pembangunan Pariwisata Berbasis Masyarakat (Tim Pengelolaan Hutan Bersama Hulu Sungai Malinau). [online] available from www.cifor.org [Accessed 1 Mei 2017].

10. Conyers, Diana. 1991. Perencanaan Sosial Di Dunia Ketiga. Yogyakarta: Gadjah Mada University Press.

11. Cooper, C. Fletcher, J. Gilbert, D.G. and Wanhill, S. 2005. Tourism: Principle and Practice, Third Edition, Harlow. Prentice Hall.

12. Dinas Pariwisata Provinsi Bali. 2017. Data Statistik Pariwisata 2016. Denpasar: CV Persada.

13. Departemen Pendidikan Nasional. .2005. Kamus Besar Bahasa Indonesia.Jakarta: Balai Pustaka.

14. Dewi, M.H.U, dkk.2013. Pengembangan Desa Wisata Berbasis Partisipasi Masyarakat Lokal Di Desa Wisata Jatiluwih Tabanan, Bali. [online] halaman 117-226. Available from https://jurnal.ugm.ac.id/kawistara/article/download/3976/3251.

15. Dewi, M.H.U. 2014. "Partisipasi Masyarakat Lokal Dalam Pengembangan Desa Wisata di Kabupaten Tabanan, Bali" (disertasi). Yogyakarta: Universitas Gadjah Mada.

16. Dinas Pariwisata Provinsi Bali dan Program Studi Pariwisata Universitas Udayana, 2003, Studi Pengembangan Desa Wisata Ambengan Berbasiskan Budaya dan Kerajinan Rakyat. Denpasar: Dinas Pariwisata Provinsi Bali.

17. Direktorat Jenderal Pengembangan Destinasi Pariwisata. 2014. Pedoman Pengembangan Desa Wisata. Jakarta: Kementerian Pariwisata dan Ekonomi Kreatif.

18. Ghozali, Imam. 2011. Structural Equation Modeling Metode Alternative dengan Partial Least Square.Semarang: Badan Penerbit Universitas Diponegoro.

19. Goodwin, H.1996. In Pursuit of Ecotourism, Biodiversityand Conversation, Netherland: Springer.

20. Hadiwijoyo, Suryo S.2012. Perencanaan Pariwisata Pedesaan Berbasis Masyarakat (Sebuah Pendekatan Konsep) $1^{\text {st }} \mathrm{ed}$, Yogyakarta: Graha Ilmu.

21. Kali, Agustinus.2011. Analisis Partispasi Masyarakat terhadap Perencanaan dan Pembangunan PLTMH di Paneki Desa Pombewe Kecamatan Biromaru Kabupaten Sigi. Available from http://jurnal.untad.ac.id/jurnal[Accessed 7 Agustus 2017].

22. Kode Etik Kepariwisataan Dunia.2009. Available from: http://www.kemenpar.go.id [Accessed 1 Juni 2017].

23. Manupassa, Erine Arneta,2011. "Peran Sektor Swasta Dalam Pengembangan Pariwisata Bahari di Kecamatan Nusaniwe Kota Ambon" (thesis). Yogyakarta: Universitas Gadjah Mada.

24. Menteri Pariwisata RI. 2016. Peraturan Menteri Pariwisata Republik Indonesia no.14

25. Mertha, I Wayan,2015. "Partisipasi Masyarakat dan Peran Pemerintah Dalam Mewujudkan Destinasi Pariwisata Berkualitas (Studi di Batur Global Geopark Kintamani)" (disertasi). Denpasar: Universitas Udayana.

26. Muhammad Chusnul Khitam.2012. "Kerjasama Antar Pemerintah Daerah, Swasta, dan Masyarakat Dalam Pengembangan Pariwisata". Journal Universitas Lamongan,Journal.unisla.ac.id.

27. Nalayani, Ni Nyoman Ayu Hari.2016 "Evaluasi dan Strategi Pengembangan Desa Wisata di Kabupaten Badung, Bali", JUMPA 2\{2\}:189-198.

28. Nurhidayati, Sri Endah. 2012. "Penerapan Prinsip Community Based Tourism (CBT) Dalam Pengembangan Agrowisata di Kota Batu Jawa Timur". Jejaring Administrasi Publik, Journal.unair.ac.id.

29. Parma, Gede. 2011. Faktor-Faktor Pendorong Partisipasi Masyarakat dalam Festival Pesona Pulau Serangan di Kota Denpasar. [online] available from https://ejournal.undiksha.ac.id [ Accessed 10 Mei 2017]. 
30. Pasaribu Rowland. Pembangunan Daerah. [online] available from rowland_pasaribu.staff.gunadarma.ac.id [ Accessed 10 Mei 2017]

31. Permanasari, Ika Kusuma.2011. "Pemberdayaan Masyarakat melalui Desa Wisata dalam Usaha Peningkatan Kesejahteraan (Desa Candirejo, Magelang, Jawa Tengah)" (thesis). Jakarta. Universitas Indonesia.

32. Pitana, I Gede. 1999. Pelangi Pariwisata Bali: Kajian Aspek Sosial Budaya Kepariwisataan Bali di Penghujung Abad. Denpasar: Balai Pustaka.

33. Pitana, I Gede dan Gayatri, Putu.2005. Sosiologi Pariwisata. Yogyakarta: Andi.

34. Poerwadarminta, W.J.S.2003. Kamus Umum Bahasa Indonesia.Jakarta: Balai Pustaka.

35. Prasiasa, Oka Dewa Putu dan Widari, Diyah Sri Dewa Ayu. 2017. Desa Wisata, Potensi dan Strategi Pengembangan. Denpasar: Pustaka Larasan.

36. Priasukmana, Soetarso dan Mulyadin, Mohamad. 2001. Pembangunan Desa Wisata: Pelaksanaan Undang-Undang Otonomi Daerah. Info Sosial Ekonomi. Vol.2 No.1 (2001) pp..37-44.

37. Pretty, Jules N, 1995. Participatory Learning For Sustainable Agriculture, UK: International Institute for Environment and Development.

38. Rafael Modestus Ziku. 2013. "Partisipasi Masyarakat Desa Komodo dalam Pengembangan Ekowisata di Pulau Komodo, Manggarai Barat" (thesis). Denpasar: Universitas Udayana.

39. Rahadiani, AA. Sagung Dewi, 2014 "Partisipasi Masyarakat sekitar Danau Beratan dalam Konservasi Sumber Daya Air" (thesis). Denpasar: Universitas Udayana.

40. Riska, Wulandari, 2013. "Analisis Partisipasi Masyarakat dan Kepemimpinan Terhadap Tingkat Keberhasilan Proyek PNPM Mandiri Pedesaan Di Kecamatan Gerokgak, Buleleng" (thesis). Denpasar.Universitas Udayana.

41. Sen, Amartya.1999. Development as Freedom. New York.

42. Soekanto, Soerjono. 2009. Sosiologi Suatu Pengantar.Jakarta: Rajawali Pers.

43. Soetrisno, Loekman, 1995. Menuju Masyarakat Partisipatif. Yogyakarta: Kanisius.

44. Suansri, Potjana. 2003. Community Based Tourism Handbook. Thailand: REST Project.

45. Suasapha, Anom Heri.2015. "Implementasi Konsep Pariwisata Berbasis Masyarakat dalam Pengelolaaan Pantai Kedonganan sebagai Daya Tarik Wisata" (thesis). Denpasar.Universitas Udayana.

46. Sudibyo, Pulung R.2006. Partisipasi Masyarakat Sub Urban dalam Pembangunan Kota Malang. Jurnal Fakultas PertanianUniversitas Muhammadiyah. [online] Available from http://dp2m.umm.ac.id/files/file/jurnal\%20Humanity\%20Vol_1,\%20No_2,\%20Maret\%202 006/1_\%20Rahmad\%20Pulung\%20Sudibyo.pdf[accessed 5 Mei 2017].

47. Sugiyono. 2014. Metode Penelitian Bisnis (pendekatan kuantitatif, kualitatif dan R\&D). Bandung: Alfabeta.

48. Tim Peneliti Ekonomi Pembangunan Pariwisata. 2014. Penelitian Pengembangan Pariwisata Berbasis Kerakyatan (CBT) Bali Utara dalam Rangka Pemerataan Pendapatan. [onlne] Denpasar.Universitas Udayana. Tersedia di http://erepo.unud.ac.id.

49. Todaro, Michael dan Smith, Stephen. 2009. Pembangunan Ekonomi. Jakarta: Erlangga.

50. Tosun, Cevat dan Timothy, Dallen J.2003.Arguments for Community Participation in the Tourism Development Process. The Journal of Tourism Studies. Vol.14 No.2.

51. http://www.bps bali.go.id, downloaded on $12^{\text {th }}$ May 2017.

52. http://www.kemendagri.go.id. Perkembangan Paradigma Good Governance.2014, downloaded on $8^{\text {th }}$ May 2017.

53. http://kbbi.web.id, downloaded on $12^{\text {th }}$ May 2017.

54. http://www.kemenpar.go.id, downloaded on $15^{\text {th }}$ October 2017.

55. http://travel.kompas.com, downloaded on $8^{\text {th }}$ May 2017.

56. http://www.rri.co.id, downloaded on $10^{\text {th }}$ September 2017

57. http://www.unescap.org. What is Good Governance, downloaded on $8^{\text {th }}$ May 2017. 